\title{
Biologi Ikan Kembung Rastrelliger spp, (Actinopterygii : Scombridae) : Ditinjau dari aspek Panjang Berat dan Indeks Kematangan Gonad Di Perairan Semarang
}

\author{
Candrika Pratama*, Retno Hartati, Sri Redjeki \\ Departemen IImu Kelautan, Fakultas Perikanan dan IImu Kelautan, Universitas Diponegoro \\ JI. Prof. H. Soedarto S.H, Tembalang,Semarang, Jawa Tengah 50275 Indonesia \\ *Corresponding author, e-mail: candrikapratama@gmail.com
}

\begin{abstract}
ABSTRAK : Ikan kembung (Rastrelliger spp) merupakan salah satu ikan pelagis yang hidup di perairan bersalinitas tinggi dan suka hidup bergerombol. Semakin meningkatnya permintaan akan ikan membuat semakin tinggi penangkapan ikan yang dilakukan. Penelitian ini bertujuan mengetahui tingkat kematangan gonad ikan kembung (Rastrelliger spp) dan mengetahui hubungan antara panjang dengan berat, hubungan antara berat dengan fekunditas, dan hubungan antara berat gonad dengan IKG (Indeks Kematangan Gonad) dari ikan kembung (Rastrelliger spp).Sebanyak 80 ekor Ikan Kembung yang didapatkan dari pasar kobong diukur panjang total dan ditimbang beratnya. Kemudian dilakukan pembedahan untuk diamati jenis kelamin dan tingkat kematangan gonadnya. Penelitian ini meliputi: Indeks Kematangan Gonad, Tingkat Kematangan Gonad, fekunditas dan rasio kelamin. Pengamatan tingkat kematangan gonad dilakukan untuk menentukan indeks kematangan gonad (IKG). Tingkat kematangan gonad ikan kembung (Rastrelliger spp) terdiri dari TKG I sampai TKG V. Nilai IKG yang didapatkan untuk ikan jantan berkisar 0,14-6,42\% dan betina berkisar 0,64-7,25\%, hal tersebut menunjukkan bahwa nilai tersebut bervariasi antara ikan jantan dan betina. Hasil penelitian dengan 80 sampel ikan kembung menunjukkan rasio kelaminnya tidak seimbang yaitu 42,5:57,5 dimana angka jantan lebih tinggi. Pertambahan ukuran panjang memberikan pengaruh yang nyata terhadap fekunditas, pertambahan ukuran panjang ikan kembung betina memberikan pengaruh yang nyata terhadap berat, pertambahan ukuran panjang ikan kembung jantan memberikan pengaruh yang nyata terhadap berat. Sedangkan berat ikan betina tidak memberikan pengaruh yang nyata terhadap IKG dan berat ikan jantan memberikan pengaruh yang nyata terhadap IKG
\end{abstract}

Kata kunci : Rastrelliger spp., TKG, IKG, Fekunditas

\section{Biology of Rastrelliger spp, (Actinopterygii: Scombridae): Judging from aspects of Length Weight and Gonad Maturity Index in Semarang Waters}

ABSTRACT : Rastrelliger spp is one of the pelagic fish that live in high salinity and like to live in groups. The increasing demand for this fish, makes the catching activity of this fish grow higher. The aim of the research is to know the Gonad Maturation Stage (GMS) of Rastrelliger spp to know the relationship between length and weight, the relationship between weight with fecundity, and relationship between gonad weight and Gonad Maturation Index from Rastrelliger spp. 80 samples of Rastrelliger spp that were obtained from the market were measured, the measurement included were length and weight. And then a surgery was performed to examine their sex and their Gonad Maturation Stage. In the end to obtain the results of its fecundity, its gonad were taken and the weight was measured. GMI. Gonad maturation stage of Rastrelliger spp fish was I-V. the range of GMI for male fish was 0,14-6,42\% and female 0,64-7,25\%. That were indicated a various values of GMI male and female fishes. The result of research with 80 samples of Rastrelliger spp showed unbalanced sex ratio 42,5: 57,5 where male number was higher. The addition of length measure gave a real effect to fecundity, the increase of length of female gave a significant effect on the weight, the increase of length of male gives a real effect on the weight. While the weight of female fish did not give a real effect on GMI and the weight of male fish gives a real effect on GMI.

Keywords : Rastrelliger spp., GMS, GMI, Fecundity 


\section{PENDAHULUAN}

Produksi perikanan pelagis di Provinsi Jawa Tengah didominasi oleh jenis ikan layang, ikan tembang, ikan lemuru, ikan selar, ikan kembung, ikan tongkol krai dan ikan peperek. Ikan kembung (Rastrelliger spp) merupakan salah satu ikan pelagis yang hidup di perairan bersalinitas tinggi dan suka hidup bergerombol (Burhanuddin, 1984). Ikan ini berpotensi di Indonesia dan hampir di seluruh perairan Indonesia ikan ini tertangkap baik dalam jumlah besar maupun sedikit. Ikan kembung masih berkerabat dengan ikan tenggiri, tongkol, tuna, madidihang, dan makerel. Produksi Ikan Kembung di Provinsi Jawa Tengah mencapai 9.928,8 ton pada tahun 2010 dan di Kota Semarang produksi yang dihasilkan seberat 10 ton (KKP, 2013).

Indeks kematangan Gonad (IKG) merupakan aspek penting dalam biologi perikanan dimana nilai IKG digunakan sebagai acuan prediksi kapan ikan tersebut akan siap melakukan pemijahan (Patriono et al., 2010). Dengan begitu penangkapan pada waktu ikan mencapai IKG maksimum dapat ditekan agar keberlangsungan dan ketersediaan ikan kembung diperairan Semarang terjaga.

Pada umumnya proses reproduksi ikan dapat dibagi dalam tiga periode yaitu prapemijahan, periode pemijahan, periode pasca pemijahan. Pengetahuan mengetahui hubungan panjang berat dan indeks kematangan gonad dapat memberikan informasi mengenai rasio kelamin, indeks kematangan gonad serta hubungan panjang berat dan indeks kematangan gonad dari lkan kembung dari perairan Semarang.

Ikan kembung merupakan komoditas tinggi di Propinsi Jawa Tengah. Kondisi ini menyebabkan semakin tingginya tingkat penangkapan ikan. Tanpa adanya pengelolaan yang baik terhadap penangkapan ikan kembung yang berlangsung secara terus menerus dikhawatirkan akan membuat terjadinya penurunan populasi dari ikan kembung yang dapat mempengaruhi ekosistem di perairan laut Jawa Tengah.

\section{MATERI DAN METODE}

Materi yang digunakan pada penelitian adalah ikan kembung (Rastrelliger spp). Ikan yang digunakan sebagai sampel berasal dari Perairan Semarang. Pengambilan sampel dilakukan melalui penangkapan oleh nelayan. dengan lokasi pengambilan sampel di Pasar Ikan Kobong, Semarang.. Alat dan bahan yang digunakan meliputi; timbangan elektronik, meteran, gunting bedah, pinset, mikroskop binokuler, sedwickrafter, aquades, alkohol 95\%.

Metode yang digunakan dalam penelitian ini adalah metode survei yang bersifat deskriptif. Notoadmojo (2002), metode survei merupakan metode yang dilakukan terhadap objek yang cukup banyak dalam kurun waktu tertentu. Namun, objek yang diteliti tidak seluruhnya dikaji, tetapi hanya sebagian dari beberapa populasi

Metode pengambilan sampel ikan kembung yang didapatkan dari pedagang Pasar Kobong, Semarang. Jumlah ikan kembung yang di ambil adalah 80 ekor. Selanjutnya ikan kembung dimasukkan ke dalam cool box yang berisi es batu. Kemudian sampel ikan kembung di bawa ke laboratorium untuk proses penngamatan

Sampel ikan Kembung diukur panjang totalnya dengan meteran (ketelitian $\mathrm{mm}$ ) yaitu perhitungan panjang ikan dari ujung mulut hingga ujung ujung ekor. Berat dari masing-masing ikan kembung diukur menggunakan timbangan digital.

\section{Analisis Data}

Data-data yang diperoleh selama penelitian; hasil pengukuran panjang berat, tingkat kematangan gonad (TKG), indeks kematangan gonad (IKG), dan fekunditas. Setelah itu, data tersebut digambarkan dalam bentuk grafik scatter plot untuk mengetahui persebaran pembacaan data dalam grafik.

Menurut Effendie (1997), berat dapat dikonversikan sebagai suatu fungsi dari panjang, hubungan pajang dengan berat hampir mengikuti hukum kubik yaitu bahwa berat ikan sebagai pangkat tiga dari panjangnya. Dalam suatu bentuk rumus yang umum yaitu : $\log W=\log a+b$ Log L. Perbandingan antara jumlah ikan jantan dan ikan betina, dengan sex rasio ini diharapkan 
perbandingan jenis kelamin ikan jantan dan betina diharapkan seimbang, bahkan diharapkan jumlah betina lebih banyak daripada yang jantan sehingga populasinya dapat dipertahankan walaupun ada kematian alami dan penangkapan. Suhendrata et al., (1991). Rasio kelamin jantan dan betina dapat dihitung dengan enggunakan persenatase rumus (Zairin, 2002):

$$
P j=\frac{A}{B} \times 100 \%
$$

Keterangan: Pj : Proposisi Jenis; A : Jumlah jenis ikan tertentu (jantan/betina); B : Jumlah total individu ikan yang ada

\section{Indeks Kematangan Gonad (IKG)}

Indeks Kematangan Gonad dihitung dengan membandingkan berat gonad dengan berat ikan yakni sebagai berikut:

$$
I K G=\frac{B g}{B t} \times 100 \%
$$

Keterangan : IKG : Indeks Kematangan Gonad; Bg : Berat gonad ikan (gram); Bt : Berat tubuh ikan (gram)

Fekunditas dihitung pada kondisi Tingkat Kematangan Gonad maupun Indeks Kematangan Gonad yang tinggi (III dan IV) :

$$
F=\frac{B g}{B s} x F s
$$

Keterangan: F : Jumlah seluruh telur; Bg : Berat seluruh gonad; Bs: Berat sebagian kecil gonad; Fs : Jumlah telur pada sebagian gonad.

Hubungan antara Parameter dengan Aspek Reproduksi dianalisa dengan menggunakan Korelasi dibantu oleh software SPSS

\section{HASIL DAN PEMBAHASAN}

Penelitian telah dilakukan dari bulan April 2018 terhadap ikan Kembung (Rastrelliger spp) sebanyak 80 ekor (46 ekor jantan dan 34 ekor betina). Ikan jantan memiliki panjang $200-272 \mathrm{~mm}$ dengan berat 80-185 g, sedangkan ikan betina memiliki panjang 211- $260 \mathrm{~mm}$ dengan berat 95$195 \mathrm{~g}$. Ikan jantan memiliki panjang 200-272 mm dengan berat 80-185 g, sedangkan ikan betina memiliki panjang 211- $260 \mathrm{~mm}$ dengan berat 95-195 g. Jumlah ikan kembung betina sebanyak 34 ekor , mempunyai nilai $a=-216,45$; nilai $b=1,5285$; Adanya hubungan antara panjang ikan dan

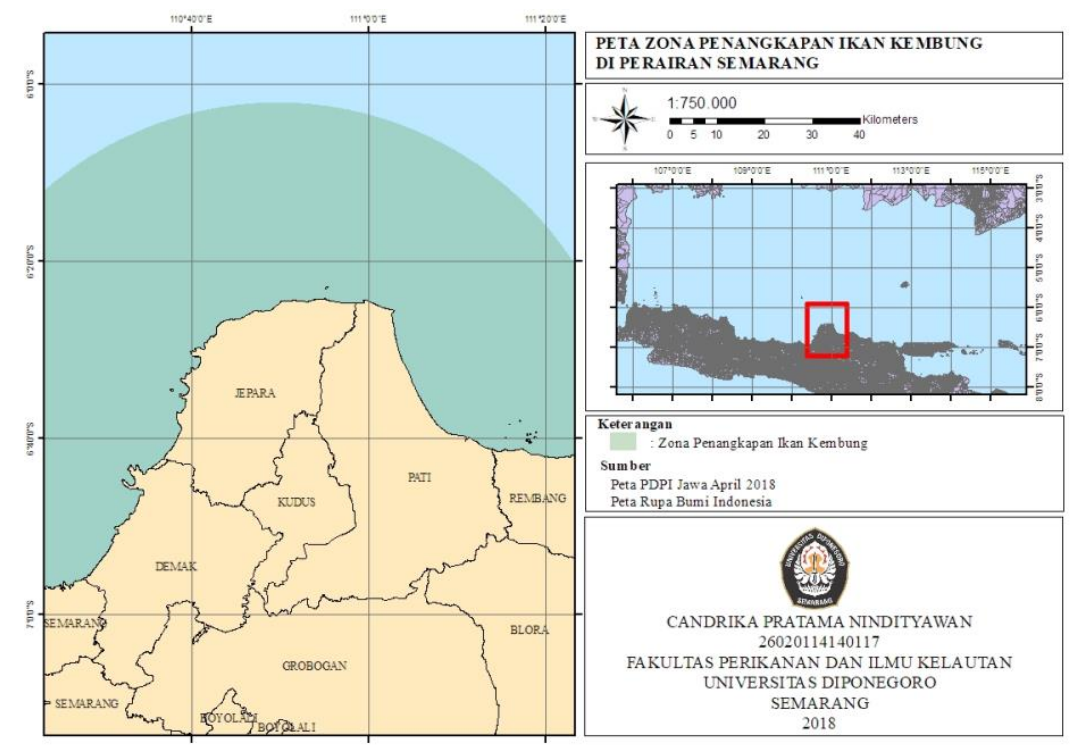

Gambar 1. Peta Zona Penangkapan Ikan Kembung di Perairan Semarang 
berat adalah kuat positif dengan Nilai koefisien korelasi $r=0,788$; dan Nilai $R^{2}=0,621$ menunjukkan bahwa berat dipengaruhi oleh panjang sebanyak $62,1 \%$. Kemudian berdasarkan hasil pengukuran ikan Kembung jantan sebanyak 46 ekor didapatkan nilai $a=-168,99$; nilai $b=$ 1,3146. Adanya hubungan antara panjang ikan dan berat adalah kuat positif dengan Nilai koefisien korelasi $r=0,77$; dan Nilai $R^{2}=0,604$ yang menunjukan bahwa berat dipengaruhi oleh panjang sebanyak 60,4 \%. Kedua hasil persamaan Ikan Kembung tersebut memiliki nilai kurang dari 3 , yaitu $b=1,3146$ untuk ikan jantan, dan $b=1,5285$ untuk ikan betina.

Hubungan panjang dan berat sering diidentikan dengan dengan mengikuti hukum kubik yaitu berat merupakan pangkat tiga dari panjangnya (Effendie, 2002). Akan tetapi kenyataanya tidak selalu demikian, sehingga penilitian ini sangat diperlukan untuk mengetahui secara menyeluruh antara hubungan panjang dan berat ikan Kembung (Rastrelliger spp) baik jantan maupun betina. Pertumbuhan ialah penambahan ukuran baik panjang maupun berat dimana banyak faktor yang mempengaruhinya yaitu genetik, hormon, dan lingkungan (Fujaya, 2004).

Setelah dilakukan analisa, didapatkan persamaan regresi untuk ikan jantan adalah $y=1,3146 x-$ 168,99; sedangkan persamaan yang didapat untuk ikan betina adalah $y=1,5285 x-216,45$. Kedua hasil persamaan Ikan Kembung tersebut memiliki nilai kurang dari 3, yaitu $b=1,3146$ untuk ikan jantan, dan $b=1,5285$ untuk ikan betina. Menurut Effendie (2002), jika nilai b kurang dari 3 maka pertambahan panjang lebih cepat daripada pertambahan berat atau dapat disebut allometrik negatif.



Gambar 2. Hubungan Panjang Berat pada Ikan Kembung Betina

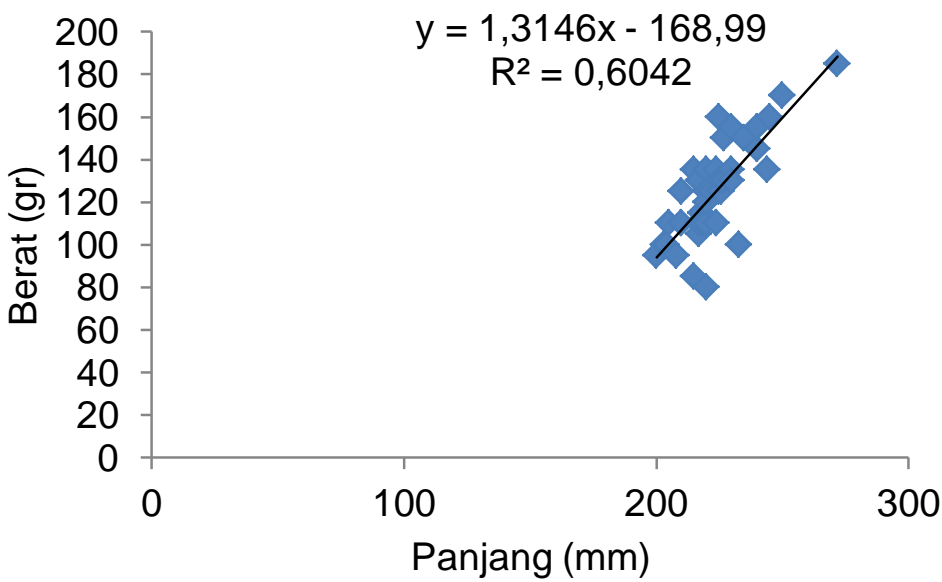

Gambar 3. Hubungan Panjang Berat pada Ikan Kembung Jantan 
Dapat dilihat pada grafik hubungan panjang dan berat ikan kembung baik jantan maupun betina, dapat diliat bahwa titik-titik yang berada diatas garis maupun dibawah garis persamaan regresi titik-titik yang tersebar menunjukkan nilai logaritma berat yang sebenarnya sedangkan garis lurus merupakan nilai berat perhitungan (Effendie,1979). Titik yang berada diatas garis regresi menyatakan bahwa nilai logaritma berat sebenarnya lebih besar dari logaritma perhitungan. Dan jika nilai logaritma berat sebenarnya lebih kecil maka titik akan berada dibawah garis regresi.

\section{Rasio Kelamin}

Dari hasil perhitungan rasio kelamin menunjukan bahwa persentase hasil tangkapan ikan Kembung dapat dikatakan berimbang, sehingga proses reproduksi diperairan tersebut dapat dikatakan baik. Maka perbandinganya adalah 42,5:57,5. Menurut Wahyuono et al, (1983), yaitu apabila jantan dan betina seimbang atau betina lebih banyak dapat diartikan bahwa populasi tersebut ideal untuk mempertahankan kelestarian. Bahkan diharapkan bahwa lebih banyak jumlah betina.

\section{Tingkat Kematangan Gonad}

Tingkat kematangan gonad ikan Kembung didapatkan tingkat kematangan gonad yang bervariasi hal tersebut berarti ikan Kembung di duga memijah sepanjang tahun. Tingkat Kematangan Gonad didapatkan hasil prosentase untuk Ikan Kembung betina didominasi oleh TKG III dengan prosentase sebesar 35,29 \% ; sedangkan utuk Ikan Kembung jantan didominasi pada TKG II dengan prosentase sebesar 39,13\% .Dari hasil ini didapatkan tingkat kematangan gonad yang bervariasi hal tersebut berarti ikan Kembung di duga memijah sepanjang tahun. Hal ini juga ditemukan pada penelitian Ikan Kembung oleh Sarasati (2017), bahwa ikan dengan TKG III dan TKG IV ditemukan dalam setiap bulan pengamatan, dan juga TKG I dan TKG II pada ikan jantan lebih banyak daripada ikan betina pada bulan April. Menurut Effendie (2002), prosentase komposisi tingkat kematangan pada setiap saat dapat dipakai untuk menduga terjadinya pemijahan dan persentase yang tinggi dari tingkat kematangan gonad yang besar merupakan puncak pemijahan walaupun pemijahanya sepanjang tahun.

Dari hasil pengamatan Tingkat kematangan gonad dan Indeks kematangan gonad, rata rata nilai Indeks kematangan gonad pada ikan betina lebih besar daripada ikan jantan. Nilai IKG tertinggi pada ikan betina adalah 5,200 \% sedangkan pada Ikan jantan adalah 3,544 \% ; hal ini sesuai dengan yang dilaporkan oleh Nasution (2014), bahwa nilai IKG tertinggi betina adalah 5\% dan jantan adalah 3\%. Hasil ini sesuai dengan pendapat Effendie (2002), bahwa ikan betina memiliki nilai IKG umumnya lebih besar dibanding jantan dimana pertambahan berat gonad pada ikan betina adalah 10-25\% dan pertumbuhan berat gonad pada ikan jantan lebih kecil yaitu 5-10\% dari berat tubuhnya

\section{Indeks Kematangan Gonad}

Nilai IKG terkecil untuk Ikan Kembung jantan adalah 0,112 dan yang terbesar adalah 3,554. Sedangkan untuk Ikan Kembung betina nilai IKG terkecil adalah 1,159 dan nilai IKG terbesar adalah 5,200.

Menurut Effendie (2002), Perkembangan gonad sejalan dengan indeks kematangan gonad, dimana jika nilai indeks semakin mendekati batas kisar maksimum pada saat terjadi pemijahan. Nilai IKG yang diperolah selama penelitian adalah kurang dari $20 \%$ hal ini berarti sesuai dengan pendapat Bagenal (1978) yang menyatakan bahwa ikan mempunyai nilai IKG lebih kecil dari $20 \%$ adalah kelompok ikan yang dapat memijah lebih dari satu kali selama setahun pada setiap tahunya.

\section{Fekunditas}

Hasil Fekunditas berdasarkan TKG III dan Iv. Pada TKG III fekunditasnya 5644-16764 butir, sedangkan TKG IV fekunditasnya 12872-32416 butir. Hal ini sesuai dengan penelitian Djamali (1977) bahwa telur ikan Kembung pada tahap pertama berkisar antara 9000 - 35000 butir. Fekunditas pada setiap individu betina tergantung pada umur, ukuran, spesies, dan kondisi lingkungan seperti ketersediaan makanan (Omar, 2004). 


\section{Hubungan antara Parameter dengan Aspek Reproduksi}

Hubungan Berat dengan Indeks Kematangan Gonad, adanya hubungan antara berat dan IKG adalah sangat lemah positif dengan Nilai $R^{2}=0.0096$ berarti sebanyak $0,96 \%$ IKG di pengaruhi berat ikan. Sisanya sebanyak $99,04 \%$ di pengaruhi faktor lain.

Hubungan antara berat dan IKG adalah cukup positif dengan Nilai $R^{2}=0,2488$ berarti sebanyak $24,88 \%$ IKG di pengaruhi berat ikan. Sisanya sebanyak $75,12 \%$ di pengaruhi faktor lain. Faktor-faktor lain yang mempengaruhi kematangan gonad adalah diantaranya berat, umur, jumlah telur, dan lingkungan (Effendie, 2002). Kemudian lingkungan juga berpengaruh terhadap pertambahan berat tubuh ikan. Pada uji T. nilai sig pada panjang adalah $0,581 \geq 0,005$, maka tidak terdapat pengaruh yang signifikan antara berat ikan terhadap Indeks Kematangan Gonad (IKG).

\section{Hubungan Panjang dengan fekunditas}

Hubungan Panjang dengan fekunditas ikan dilakukan dengan sampel yang tingkat kematangan gonadnya berada pada tingkat kematangan gonad III dan IV. Hubungan antara panjang ikan dan fekunditas adalah kuat positif ditunjukan oleh besar Nilai koefisien ( $r$ ) yaitu 0,788.

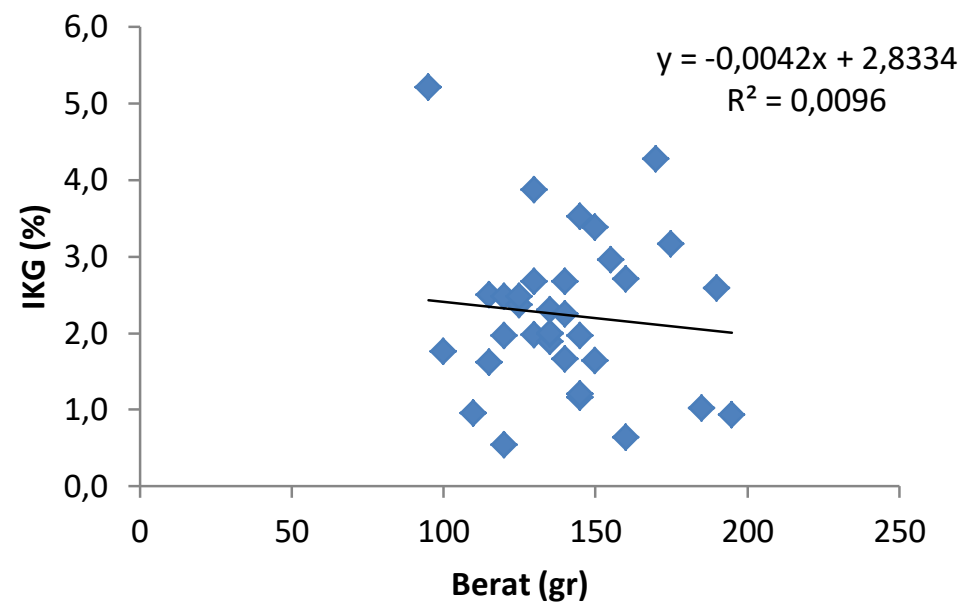

Gambar 4. Hubungan Berat dengan Indeks Kematangan Gonad Ikan kembung Betina

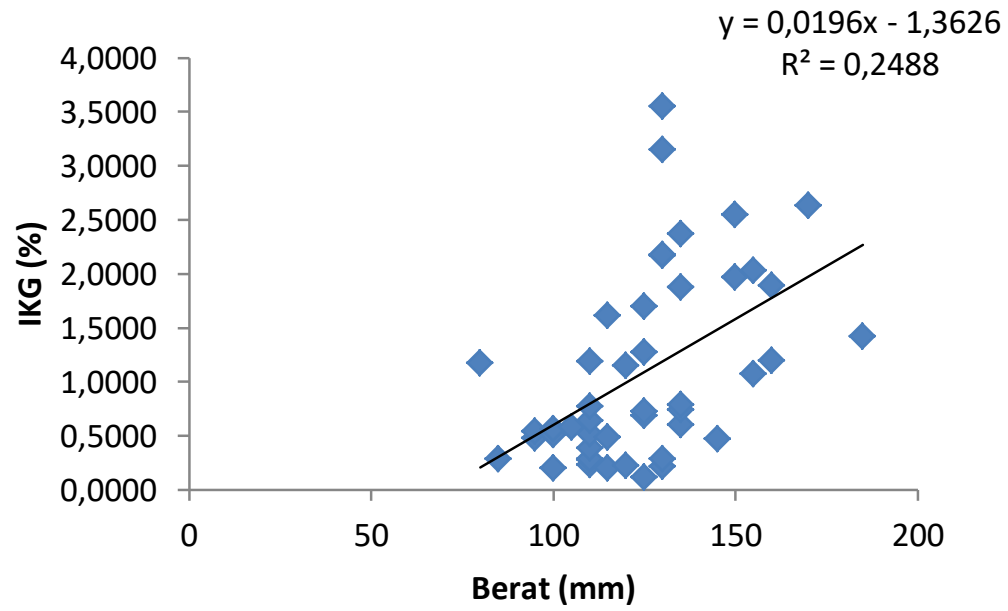

Gambar 5. Hubungan Berat dengan Indeks Kematangan Gonad Ikan Kembung Jantan 


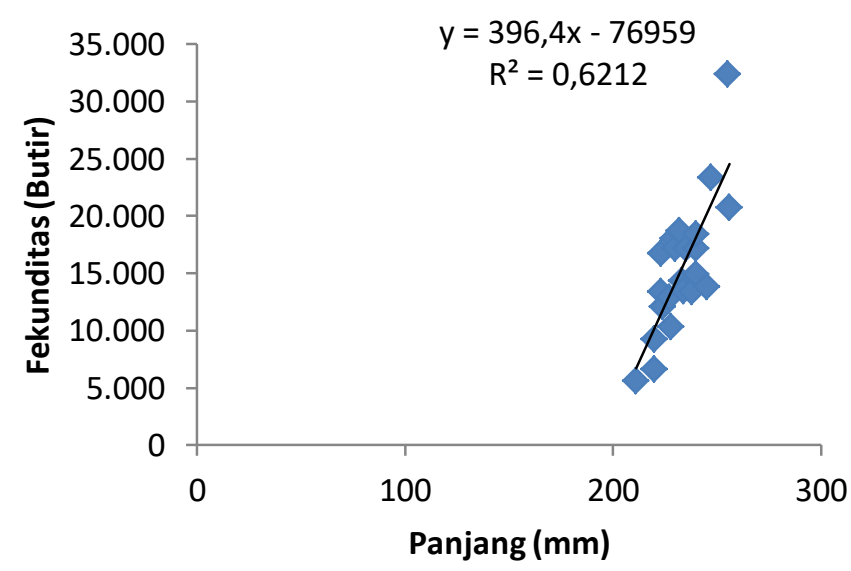

Gambar 6. Hubungan Panjang dengan Fekunditas

Hal ini diperkuat oleh pendapat Hasan (2002), bahwa $0,7<r<0,9$ maka memiliki korelasi yang sangat tinngi. Nilai $R^{2}$ adalah 0,621 berarti sebanyak $62,1 \%$ fekunditas di pengaruhi panjang ikan. Sisanya sebanyak $37,9 \%$ di pengaruhi faktor lain. Faktor lain yang mepengaruhi fekunditas diantaranya adalah berat, jumlah telur, dan juga umur (Effendie, 2002).

Menurut Nikolsky (1963), fekunditas ikan selalu diadaptasikan dengan lingkungan. Kemudian lingkungan juga berpengaruh terhadap pertumbuhan panjang dan berat tubuh ikan. Dengan ini pertambahan panjang dan berat tubuh tersebut dapat berpengaruh pada terhadap fekunditas ikan tersebut. Pada uji T. nilai sig pada panjang adalah 0,000 lebih kecil dari atau sama dengan 0,005, maka terdapat pengaruh yang signifikan antara panjang ikan terhadap fekunditas.

\section{KESIMPULAN}

Berdasarkan hasil penelitian, dapat ditarik kesimpulan bahwa Hubungan Panjang berat Ikan Kembung (Rastrelliger spp) didapatkan hasil persamaan Ikan Kembung tersebut memiliki nilai kurang dari 3 , yaitu $b=1,3146$ untuk ikan jantan, dan $b=1,5285$ menyatakan bahwa pertambahan panjang lebih cepat daripada pertambahan berat atau dabat disebut allometrik negatif. Hasil perbandingan rasio kelamin ikan Kembung yaitu sebanyak 34 ikan betina dan 46 ikan jantan adalah $42,5 \%: 57,5 \%$ atau dapat dikatakan populasinya seimbang. Tingkat kematangan gonad ikan Kembung (Rastrelliger spp) jantan dapat disimpulkan bahwa TKG I mencapai angka 32,6\% TKG II 39,13\%, TKG III 13,04\%, TKG IV 15,21\%, dan pada betina TKG I mencapai angka 2,94\% TKG II 17,65\%, TKG III 35,29\%, TKG IV 29,41\%, TKG V 14,70\%. Nilai Indeks Kematangan Gonad tertinggi untuk Ikan Kembung betina adalah 5,200 dan untuk jantan adalah 3,554 sedangkan nilai terendah adalah 0,533 untuk betina dan 0,112 untuk Jantan dan nilai Fekunditas pada TKG III berkisar 5644-16764 dan TKG IV berkisar 12872-32416

\section{DAFTAR PUSTAKA}

Bagenal, T.B. 1978. Aspect of Fish Fecundity in : Gerking SD (Ed.) Ecology of Freshwater Fish Production. Oxford : Blackwell Scientific Publication : 75-101

Burhanuddin, S., Martosuwejo, M., Adrim \& Hutomo, M.. 1984. Sumberdaya Ikan Kembung. Studi Potensi Sumberdaya Hayati Ikan. LON-LIPI. Jakarta.

Djamali, A. 1977. Penelaahan Beberapa Aspek Ikan Kembung, Restrelliger kanagurta (CUVIER) di perairan Pulau Panggang, pulau-pulau seribu oseanologi di Indonesia 8:1-10

Effendie, M.I. 1979. Metode Biologi Perikanan Cetakan Pertama. Yayasan Dewi Sri.Bogor

Effendie, M.I. 2002. Biologi Perikanan. Yayasan Pustaka Nusatama. Yogyakarta

Fujaya, Y. 2004. Fisiologi lkan Dasar Pengembangan Teknologi Perikanan. Penerbit Rineka Cipta. Jakarta 
Harianti. 2013. Fekunditas dan Diameter Telur Ikan Gabus (Channa striata Bloch, 1793) di Danau Tempe, Kabupaten Wajo. Jurnal Saintek Perikanan 8(2):8-24

Hasan, I. 2002. Pokok-Pokok Materi Statistik I (Statistik Deskriptif). Bumi Aksara : Jakarta

Hidayat, I.R.L. 2014. Analisis Tingkat Kematangan Gonad dan Fekunditas Ikan Kembung (Restrelliger sp) di Perairan Aceh Barat. Universitas Teuku Umar : Aceh

Kementerian Kelautan dan Perikanan. 2013. Profil Kelautan Dan Perikanan Provinsi Banten Untuk Mendukung Industrialisasi KP. Pusat Data, Statistik, dan Informasi Sekretariat Jenderal Kementerian Kelautan dan Perikanan, Jakarta.

Nasution, M.A. 2014. Pertumbuhan dan Reproduksi Ikan Kembung Lelaki (Rastrelliger kanugarta Cuvier 1817) yang Didaratkan di PPN Palabuhan Ratu. Fakultas Perikanan dan IImu Kelautan, Universitas Teuku Umar : Aceh

Nikolsky, G.V. 1963. The Ecology of Fishes. Academic Press.London. 352 p.

Notoadmojo, S. 2002. Metodologi Penelitian Kesehatan. Rineka Cipta. Jakarta

Omar, S.B.A. 2004. Modul Praktikum Biologi Perikanan. Jurusan Perikanan, Fakultas IImu Kelautan dan Perikanan. Universitas Hassanudin, Makasar. $168 \mathrm{Hal}$

Patriono, E., Endri, J. \& Fifi, S. 2010. Fekunditas Ikan Bilih (Mystacaleucus padangenis) di Muara Sungai Sekitar Danau Singkarak. Penelitian Sains, 13(3):55 - 58

Sarasati, W. 2017. Dinamika Populasi dan Biologi Reproduksi Multispesies Ikan Kembung (Rastrelliger faughni, R. Kangarta, R. Brachysoma) di Perairan Selat Sunda. Institut Pertanian Bogor, Bogor.

Suhendrata, T., \& Merta, I.G.S. 1991. Hubungan Panjang-Berat. Tingkat Kematangan Gonad dan Fekunditas Ikan Cakalang, Katsuwonus pelamis (Linnaeus) di Perairan Sorong. Jurnal Penelitian Perikanan Laut.

Wahyuono, H., Budiharjo, S., Wudianto \& Rustam, R. 1983. Pengamatan Parameter Biologi Beberapa Jenis Ikan Demersal di Perairan Selat Malaka Sumatera Utara. Laporan Penelitian Laut. Jakarta.

Zairin, M, Jr. 2000. Sex Reversal Memproduksi Benih Ikan Jantan dan Betina. Penebar Swadaya, Jakarta. 